\title{
Pharmacological Targeting of Pore-Forming Toxins as Adjunctive Therapy for Invasive Bacterial Infection
}

\author{
Tamara Escajadillo ${ }^{1}$ and Victor Nizet ${ }^{2, *}$ (i) \\ 1 Biomedical Sciences Graduate Program and Department of Pediatrics, School of Medicine, UC San Diego, \\ La Jolla, CA 92093, USA; tescajadillo@ucsd.edu \\ 2 Department of Pediatrics and Skaggs School of Pharmacy and Pharmaceutical Sciences, UC San Diego, \\ La Jolla, CA 92093, USA \\ * Correspondence: vnizet@ucsd.edu; Tel.: +1-858-534-7408
}

Received: 22 November 2018; Accepted: 14 December 2018; Published: 17 December 2018

\begin{abstract}
For many of the most important human bacterial infections, invasive disease severity is fueled by the cell damaging and pro-inflammatory effects of secreted pore-forming toxins (PFTs). Isogenic PFT-knockout mutants, e.g., Staphylococcus aureus lacking $\alpha$-toxin or Streptococcus pneumoniae deficient in pneumolysin, show attenuation in animal infection models. This knowledge has inspired multi-model investigations of strategies to neutralize PFTs or counteract their toxicity as a novel pharmacological approach to ameliorate disease pathogenesis in clinical disease. Promising examples of small molecule, antibody or nanotherapeutic drug candidates that directly bind and neutralize PFTs, block their oligomerization or membrane receptor interactions, plug establishment membrane pores, or boost host cell resiliency to withstand PFT action have emerged. The present review highlights these new concepts, with a special focus on $\beta$-PFTs produced by leading invasive human Gram-positive bacterial pathogens. Such anti-virulence therapies could be applied as an adjunctive therapy to antibiotic-sensitive and -resistant strains alike, and further could be free of deleterious effects that deplete the normal microflora.
\end{abstract}

Keywords: Pore-forming toxin; bacterial infection; virulence factor; pharmacology; adjunctive therapy

Key Contribution: Pharmacological neutralization of bacterial pore-forming toxins is an emerging therapeutic concept to improve patient outcomes in severe infection.

\section{Introduction}

The rapid emergence of antimicrobial resistant strains of bacteria has exceeded the rate at which anti-bacterial therapies are currently being produced. While the classical approach to drug development has focused on the enhancement of bactericidal properties of antibiotics, over-prescription coupled with non-adherence to treatment regimens has further contributed to the development of widespread resistance [1-3], underscoring the overarching need for the development of novel methods for combating bacterial infections. One possible approach that has gained attention over the past few years involves selecting bacterial virulence mechanisms as targets for therapy.

All bacteria rely on specialized virulence factors with which they can cause damage to host cells. While there exists a plethora of virulence mechanisms utilized by pathogenic bacteria to cause disease, the majority produce toxins that induce damage to either gain access to host cells for further proliferation, derive nutrients from host cells, or disrupt host cell immune function to increase their own survival, all of which may ultimately lead to host cell death. Pore forming toxins (PFTs) comprise about $25 \%$ of all known bacterial toxins, making them one of the largest classes of bacterial virulence 
factors [4-6]. All PFTs require binding in some way to a receptor on the host cell plasma membrane, where they oligomerize, form pores and alter membrane integrity $[4,7,8]$. While the mechanism of PFT pore formation may seem deceptively simple, PFTs can affect intracellular signaling cascades, dependent in part on the membrane structure the are bound to, and therefore can produce a variety of downstream responses, enhancing the pathogenicity of the bacteria that secrete them [5,6,8-12].

By preserving cell membrane integrity and viability of all host cells, including immune cells, PFT virulence factor neutralization could aid in facilitating pathogen elimination by normal immunity, while preserving the beneficial host microbiome. Given that anti-virulence strategies do not focus on directly killing the pathogen, they could provide the additional benefit of exerting less selective pressure, which may in turn result in a decreased need by the bacteria to develop resistance [13-15].

This review will focus on the non-classical approaches that have been developed toward reducing bacterial-induced damage to host cells through inhibition of secreted PFTs. These concepts have the potential to become important pharmacological strategies for improving treatment outcomes, used either independently or as an adjunct to classical antibiotic regimens.

\section{Classification of Pore-Forming Toxins}

PFTs can generally be classified into two large groups based on the secondary structure used to traverse the host cell plasma membrane, and are designated $\alpha$-PFTs, for the creation of $\alpha$-helixes, and $\beta$-PFTs, for the creation of $\beta$-barrels [16]. The $\alpha$-PFTs use clusters of amphipathic and hydrophobic helices to form pores in the target membrane $[17,18]$, and the archetypal members of this class are the colicins produced by Escherichia coli [19-21]. Additional $\alpha$-PFT members include Cry toxins of Bacillus thuringiensis [22], diphtheria toxin of Corynebacterium diphtheriae [23], and exotoxin A produced by Pseudomonas aeruginosa [24].

$\beta$-PFTs represent the majority of currently identified bacterial PFTs and are more extensively studied due to the high stability of their inter-strand hydrogens, which allows the establishment of more precise classifications [25-27]. A subset of $\beta$-PFTs can be further classified into three separate groups: hemolysins, aerolysins, and cholesterol-dependent cytolysins (CDCs) [6]. CDCs require the presence of cholesterol during at least one step of their activity; they may also be referred to as thiol-activated cytolysins due to their reported sensitivity to oxygen [28]. The CDC family is particular large, with over 20 PFTs that share common structural motifs secreted by a range of Gram-positive and Gram-negative bacteria. Among the most widely studied are streptolysin O (SLO) from Streptococcus pyogenes [29], pneumolysin (PLY) from Streptococcus pneumoniae [30], intermedilysin (ILY) from Streptococcus intermedius [31], listeriolysin O (LLO) from Listeria monocytogenes [32,33], anthrolysin $\mathrm{O}$ (ALO) from Bacillus anthracis [34] and perfingolysin O (PFO) from Clostridium perfringens [35]. Commonly studied non-CDC $\beta$-PFTs include aerolysin from Aeromonas hydrophila [36] and $\alpha$-hemolysin (Hla) from Staphylococcus aureus [37].

When their expression is activated to support key steps in bacterial pathogenesis, $\beta$-PFT monomers are secreted by their corresponding species. The $\beta$-PFT then binds to a receptor on the plasma membrane of the host cell, where it oligomerizes to form a pre-pore complex. This complex converts to the inserted pore complex upon insertion of the transmembrane $\beta$-sheet. The precise mechanistic details of pore formation have previously been reviewed in detail $[5,17,25,27,28,38-40]$. For the purposes of this review, we will primarily focus on inhibition and neutralization of $\beta$-PFTs secreted by important Gram-positive bacterial pathogens of humans.

\section{Overview of Pharmacological Approaches to Pore-Forming Toxin Inhibition}

Given the multi-step process of host cell engagement and pore formation after toxin secretion by the bacterium, there exist multiple stages at which a PFT toxin can be targeted for inhibition, both directly and indirectly. While direct toxin inhibition involves physical binding to the monomer to preclude interaction with the host cell or interruption of the oligomerization process, indirect methods have been described including prevention of binding to the host cell receptor, pore blockade 
or stimulating membrane repair pathways to boost the cell's ability to mitigate toxin-induced damage (Figure 1). Small molecules, some repurposed from other areas of medicine, liposome and nanoparticle platforms, and monoclonal antibodies or toxoid vaccine-induced humoral responses, comprise the repertoire of agents discussed in the ensuing sections.

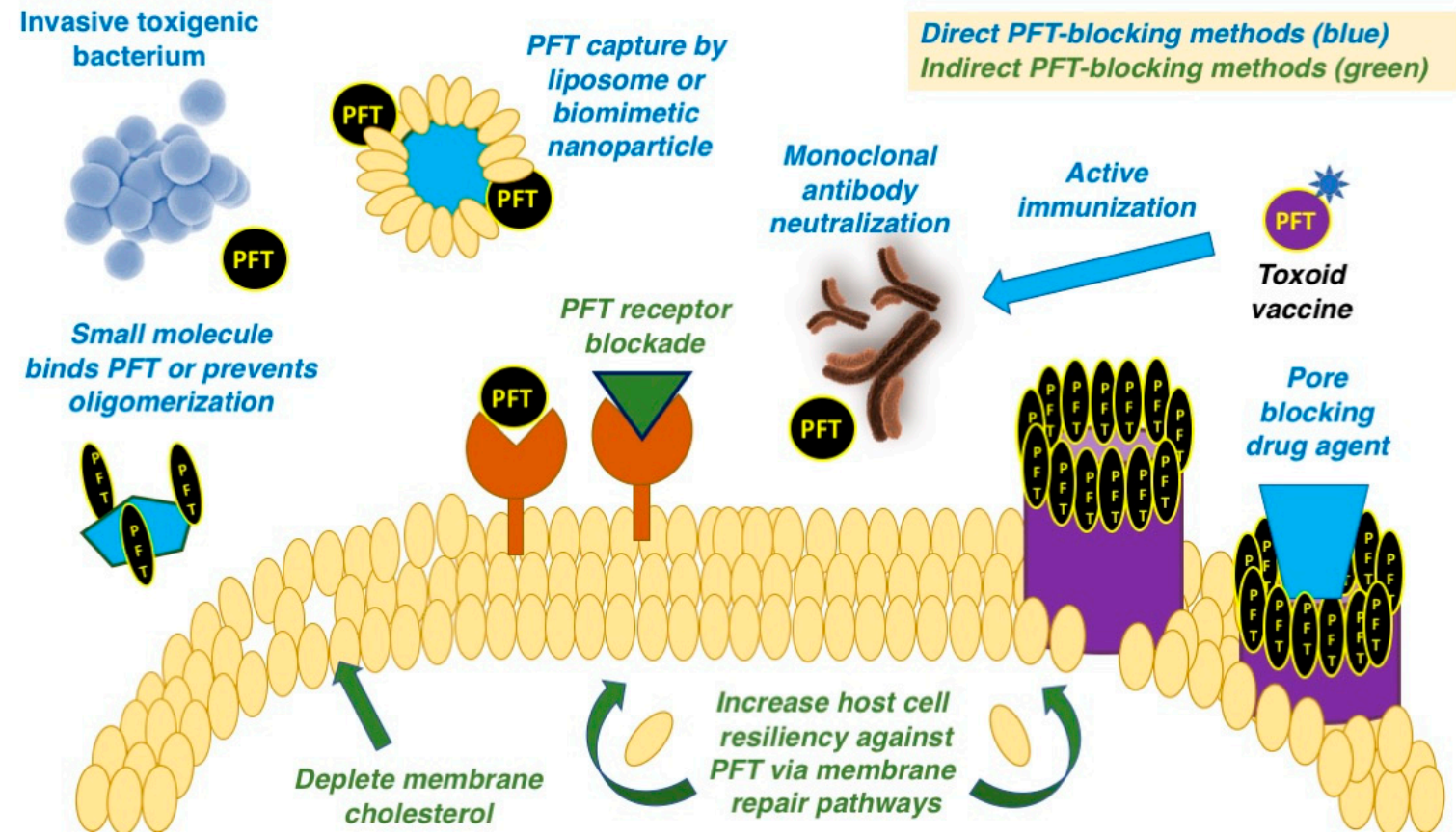

Figure 1. Overview of pharmacological strategies to counteract bacterial pore-forming toxin (PFT) virulence factors discussed in the present review. Promising examples of small molecule, antibody (passive or active immunization) and nanotherapeutic drug candidates that directly bind and neutralize PFTs, block their oligomerization or membrane receptor interactions, plug establishment membrane pores, or boost host cell resiliency to withstand PFT action have emerged.

\section{Direct Binding or Sequestration of Pore-Forming Toxins}

Direct binding to the secreted $\beta$-PFT monomer constitutes one of the most straightforward approaches to neutralization and has been one of the most extensively explored within the realm of bacterial infections. In addition, the process of pore formation is dynamic, with different structural and functional states existing in the path to pore formation [41]. Once the $\beta$-PFT has bound to its receptor on the host cell, it undergoes conformational changes and oligomerizes to form a lytic transmembrane pore domain and insert itself into the plasma membrane. The elucidation of these dynamic processes has benefited greatly from continual advances in electron microscopy, time-lapse atomic force microscopy, and X-ray crystallography, which together have allowed direct observation and precise characterization of these different stages [42-47].

\subsection{Passive Antibody Neutralization of Pore-Forming Toxins}

A variety of molecules have been discovered that are capable of directly binding to PFTs, most prominently monoclonal antibodies (mAbs). Despite being the largest category of PFT-neutralizing agents, mAbs have not been explored as extensively in the realm of antibacterial therapeutics as they have in other areas of medicine, such as oncology and viral infections [48]. mAbs are generated from an isolated B-cell clone expressing a single isotope, and then evaluated through various high-throughput protocols for epitope binning and relative affinity ranking to identify functional clones for hybridoma development [49-51].

Because of its medical importance and established role in the pathogenesis of pneumonia, skin necrosis and systemic infection, $\beta$-PFT Hla ( $\alpha$-toxin) of $S$. aureus has been a leading target 
of antibody therapeutic programs. Encouraging results from passive immunization studies with rabbit polyclonal Hla-specific antisera, generated using a purified inactive form of the toxin (HlaH35L) as the immunogen, established a first proof-of-principle [52,53], inspiring the development of several ant-Hla mAbs using large-scale libraries and high-throughput screening methods. For example, AR-301 (Salvecin ${ }^{\mathrm{TM}}$, Aridis Pharmaceuticals, Inc, San Jose, CA, USA) is a fully human monoclonal IgG1 antibody that was evaluated in a phase 2 a clinical trial as adjunctive therapy to standard antibiotics for severe culture-confirmed $S$. aureus pneumonia in ICU patients. Post-hoc subgroup analysis suggested potential benefits in reducing the duration of ventilator support in intubated patients, a trend toward faster microbiological eradication, no serious adverse events attributed to the drug, and a plasma half-life of four weeks; however, larger randomized trials would be required to better define safety and efficacy [54]. The mAb MEDI4893 (MedImmune, LLC) binds Hla through an epitope in the "rim" domain to exert a dual mechanism of neutralization: (a) preventing the toxin from adopting a pore-forming heptameric transmembrane conformation required for host cell lysis, and (b) inhibiting Hla binding to its cellular receptor, A Disintegrin and metalloproteinase domain-containing protein 10 (ADAM10) [55-57]. The safety, tolerability, pharmacokinetics, anti-Hla-neutralizing activity of MEDI4893 have recently been explored in a phase 1, double-blind, dose escalation study [58].

Still in preclinical development, other mAbs against Hla include: (a) 2A3 and its affinity-optimized variant LC10, which reduce disease severity in a murine model of $S$. aureus pneumonia $[59,60],(b) \mathrm{mAbs}$ $7 \mathrm{~B} 8$ and $1 \mathrm{~A} 9$ generated against the nontoxic $\mathrm{Hla}_{\mathrm{H} 35 \mathrm{~L}}$ mutant that prevent oligomerization of the $\beta$-PFT and provide a high degree of protection against $S$. aureus pneumonia [61], and (c) high-affinity $\mathrm{mAb}$ LTM14, derived from a phage display library, which blocks the lytic activity of Hla in a dose-dependent manner in vitro [55].

In addition to Hla, $S$. aureus strains can secrete an array of bicomponent $\beta$-PFTs, which are comprised of two subunits ( $\mathrm{S}$ and $\mathrm{F}$ ) with $\beta$-barrel structure that achieve pore-forming configuration after binding to specific cell receptors followed by hetero-oligomerization of the two subunits at the plasma membrane $[62,63]$. The oligomeric $\beta$-PFTs then create the plasma membrane pore leading to pathological ion fluxes and activation of cell death pathways. These bicomponent $\beta$-PFTs are often termed leukocidins, because of their capacity to target and functionally inactivate host neutrophils and monocyte/macrophages and include Panton-Valentine leukocidin (Luk-SF-PV or PVL) that has been epidemiologically linked to severe infections in epidemic clones of community-acquired $S$. aureus [62,63]. Indeed, passive transfer of rabbit immunoglobulin raised against LukS-PV alone protects against $S$. aureus sepsis [64]. In a search for targeted therapeutics, the mAb ASN-1 was isolated by screening a human IgG1 antibody library with a yeast selection system and found to bind four members of the S. aureus leukotoxin family of cytotoxins: LukSF-PV (Panton-Valentine leucocidin), LukED, $\mathrm{Hlg} \mathrm{AB}$, and $\mathrm{HlgCB}$, in addition to Hla [65]. A second $\mathrm{mAb}$ ASN-2 neutralized the additional S. aureus leukotoxins LukGH. ASN-1 and ASN-2 mAb were then combined in the formulation ASN-100 (Arsanis, Inc.) [66], with no dose limiting toxicity observed to date [67]. In other approaches, humanized heavy chain-only antibodies ( $\mathrm{HCAb}$ ) were generated against $S$. aureus leukocidins LukS-PV and LukF-PV and validated in vitro and in vivo, with the additional benefit of preventing toxin binding and pore formation for $\gamma$-hemolysin C (HlgC) [68].

Work to develop antibody neutralization strategies against $\beta$-PFTs from other key human pathogens has been more preliminary. The murine mAbs PLY 4 and PLY 7 effectively target the CDC PFT S. pneumoniae pneumolysin (PLY), and are directed against epitopes that have dual actions to reduce cytolytic activity and block binding to host cells, although they have not advanced to humanization protocols or clinical trials yet $[69,70]$. Passive administration of monoclonal antibodies to B. anthracis anthrolysin $\mathrm{O}(\mathrm{ALO})$ may provide a measure of host protection under specific circumstances. One $\mathrm{mAb}(64 \mathrm{~F} 8)$ reduced the cellular toxicity of rALO in vitro, and the combination of mAbs 64F8 and 80C9 was more effective than either $\mathrm{mAb}$ alone in prolonging survival in a murine systemic anthrax infection model [71]. Polyclonal antibodies raised in rabbits against mutated Y30A-Y196A C. perfringens Epsilon toxin (Etx), a $\beta$-PFT that causes enterotoxemia, neutralize the purified wild-type 
toxin in vitro [72], but have yet to proceed to mAb development or translational studies in live infection models.

\subsection{Small Molecules that Bind or Inhibit Toxin Assembly}

While there are several small molecule natural compounds reported to reduce the level of Hla production by S. aureus [73-75], a few have been studied for their direct toxin neutralizing activity, including baicalin. Baicalin is a flavonoid compound isolated from the traditional medicinal herb Scutellaria baicalensisa (Chinese skullcap), which binds Hla directly and inhibits its hemolytic activity by restraining the conformational change of the binding cavity [76]. Other flavonoids reported to inhibit Hla include apigenin, chrysin, kaempferol, luteolin, and quercetin, the natural compounds trans-resveratrol and betulinic acid [77], and the O-methylated flavone oroxylin A, which bind to the Hla active site (Thr11, Thr12, Ile14, Gly15 and Lys46) to inhibit self-assembly of the heptameric transmembrane pore [78]. Morin hydrate, another bioflavonoid, was predicted to bind to residues I107 and T109 and induce a conformational change that leads to inhibition of the self-assembly of the heptameric transmembrane pore [79]. In silico-based approaches based on key residues involved in the formation of the pore complex were used to design potential peptides for Hla inhibition, revealing the IYGSKANRQTDK peptide to both efficiently bind and disturb dimer formation [80].

Several natural product-derived compounds interfere with the oligomerization of PLY on cell membranes, although their actions have not yet been evaluated in the clinical setting. Amentoflavone (AMF; $4^{\prime}, 4^{\prime \prime \prime}, 5,5^{\prime \prime}, 7,7^{\prime \prime}$-hexahydroxy-3 $3^{\prime \prime \prime}, 8$-bi- flavone), is a flavonoid extracted from Selaginella tamariscina and other plants widely used in traditional Chinese medicine. AMF blocks the PLY oligomerization process and inhibits its cytolytic activity by binding at the cleft between PLY domains 3 and 4. [81]. Verbascoside is a phenylpropanoid glycoside that does not exhibit bacteriostatic activity, but as shown through molecular dynamics simulations and mutational analysis, inhibits PLY mediated cytotoxicity by a similar domain 3-4 cleft binding [82]. In vitro studies of the flavonoid apigenin showed direct interaction with PLY, dose-dependent attenuation of hemolytic activity, and significant protection in a murine model of pneumococcal pneumonia [83]. Finally, $\beta$-sitosterol, a plant-derived cholesterol mimic, binds PLY with high affinity via Thr-459 and Leu-460, without intervening in oligomerization [84].

Allicin, the most abundant thiosulfinate molecule found in garlic extract, blocks SLO hemolytic activity, likely by binding the cysteine residue in the toxin's binding site [85]. Glycan array analysis determined that SLO significant bound to 47 glycan structures, and upon flow cytometric analysis, free lacto- $N$-neotetraose (LNnT), which binds to SLO domain 4, blocked RBC binding, highlighting glycans as a source for other possible inhibitors of $\beta$-PFT function [86]. Via molecular modeling and mutational analysis, fisetin, a dietary flavonoid, directly engaged loops 2 and 3 of LLO, blocking cholesterol binding and reducing its oligomerization and hemolytic activity [87]. From molecular docking analysis of LLO using a library containing 200,000 drug-like compounds, one molecule (1-(4-Cyclopent-3-enyl-6, 7-dihydroxy-8-hydroxymethyl-nona-2, 8-dienylideneamino)-penta-1,4-dien-3-one) inhibited LLO oligomerization, with strong predicted binding properties and no undesirable toxicity [88].

\subsection{Inhibition of Pore-Forming Toxins through Decoy Capture}

A characteristic that all $\beta$-PFTs share in common is the requirement to bind the plasma membrane of the target host cell in some capacity. This principle inspired the development of liposomal targets that can serve as decoys for toxins by mimicking the lipid composition of natural host membranes. Liposomes are synthetic, spherical, nanoscale multilamellar or unilamellar bilayer vesicles composed of a variety of lipids that have been used for various commercial applications, including enhancing drug delivery and enhancing signaling for medical diagnostics [89,90]. These lipid layers can be modeled after the distinct microdomains known as lipid rafts which, while unstable in vivo, can be stably artificially created within liposomes. The liposomes can be optimized to enhanced selectivity for bacterial toxins by using specific concentrations of cholesterol:sphingolyelin (Ch:Sm) [91]. Liposomes 
(66 mol/\% cholesterol) are able to bind CDCs and Hla, while a mixture of cholesterol:sphingolyelin liposomes (66 mol/\% cholesterol) with sphingomyelin only liposomes (Ch:Sm $+\mathrm{Sm}$ ) sequestered a larger array of bacterial toxins. One can see improved therapeutic efficacy of antibiotics used in combination with their liposomal formulations as adjunctive therapy during in vivo $S$. aureus and $S$. pneumoniae bacteremia models [91]. These studies served as the basis for the development of CAL02, a new liposomal formulation marketed by the Swiss-based company Combioxin SA. CAL02 recently completed Phase I clinical trials for neutralization of a large panel of bacterial toxins via recognition of the artificially engineered lipid rafts on the liposomes.

Despite the promising nature of liposomal toxin decoy capture platforms, these artificial nanoparticle formulations face many challenges, including rapid opsonization and clearance by macrophages and the need to tailor liposomal formulations to specific concentration ranges [92,93]. Various attempts to circumvent this problem by applying stealth coatings have raised the issue of off-target immunological responses [94]. These considerations recently led to the development of natural host cell membrane camouflaged nanoparticles, which significantly enhanced bioavailability. This characteristic is key for absorbing toxins in the bloodstream while providing the same complex surface chemistry of the biological cell from which they are derived [95]. RBC membrane-derived nanoparticles internally stabilized with a poly(lactic-co-glycolic-acid) (PLGA) core have been shown to bind and retain a variety of $\beta$-PFTs including Hla SLO, and LLO [96], and significantly reduced the ability of these toxins to induce host cell damage both in vitro and in mouse challenge models [96-99]. Conceivably, an expansion of this approach with the corresponding host target membranes has the potential to detoxify all membrane-damaging bacterial PFTs.

\section{Inhibition of Host Cell Receptors or Uptake of Pore-Forming Toxins}

PFTs recognize target cells by binding to different receptors including sugars, lipids and proteins on the plasma membrane, yet not all receptors have been identified, leaving this an ongoing area of research [6]. Research into the mechanism of action of $S$. aureus Hla has shown that the protein receptor ADAM10, a zinc-dependent metalloprotease, is required for toxin binding to the eukaryotic cell membrane and consequent toxicity [100]. The hydroxamate inhibitor GI254023X inhibits ADAM10 by fitting into the S1 specificity pocket [101], attenuating epithelial barrier dysfunction by preventing the cleavage of the junctional protein E-cadherin [102]. GI254023X treatment significantly decreased lesion size in a murine model of $S$. aureus necrotizing skin infection [103]. Co-receptors for another $S$. aureus $\beta$-PFT, leukocidin LukED, include the human immunodeficiency virus (HIV) co-receptor or CC-chemokine receptor type 5 (CCR5) and CXC-chemokine receptor type 1 and 2 (CXCR1 and CXCR2). Activity of LukED can be efficiently blocked using CCR5 receptor agonists and the FDA-approved HIV drug maraviroc [104,105].

Intermedilysin (ILY), a CDC from Streptococcus intermedius, in addition to cholesterol binds human complement regulator CD59, a glycosylphosphatidylinositol (GPI)-anchored cell-surface receptor, thereby promoting oligomerization and pore formation on the host cell membrane $[11,106,107]$. The crystal structure of CD59 bound to ILY was solved and guided synthesis of a peptide based on the binding site comprised of ILY residues 438-452; this peptide successfully competed for CD59 binding and inhibited ILY pore formation in vitro [108]. Another study characterized the mechanism of the 114-amino acid recombinant form of the 4th domain of intermedilysin (rILYd4) as another CD59 inhibitor. Upon binding to rILYd4, CD59 is internalized and is degraded in lysosomes within minutes, while the remaining rILYd4.CD59 complexes are shed from the cell [109]. Major binding targets for the Aeromonas $\beta$-PFT aerolysin are also GPI-anchored surface receptors, including T-lymphocyte protein (Thy-1) [12]. Given the ability of synthetic analogs of GPIs to inhibit binding of a related toxin (CAMP factor), this approach could conceivably apply to aerolysin as well [110]. LeX/sLeX glycans have recently been identified as receptors for the pneumococcal $\beta$-PFT PLY that contribute to RBC lysis. When cells were preincubated with anti-sLeX and anti-LeX monoclonal antibodies prior to PLY exposure, hemolytic activity was inhibited [86]. 
Cholesterol is widely understood to be essential for pore formation of CDCs and appears to play multiple roles, including targeting, promotion of oligomerization, triggering a membrane insertion competent form, and stabilizing the membrane pore [35]. It has been suggested that the extent of toxin binding and size of the oligomers is dependent upon the cholesterol concentration in the membrane [111]. Thus, it is possible that pharmacological approaches to reduce cell membrane cholesterol could have a beneficial effect of reducing $\beta$-PFT pore formation, especially with the CDC subclass of toxins. Statins, competitive inhibitors of 3-hydroxy 3-methylglutaryl coenzyme A (HMG-CoA), the rate-limiting enzyme in cholesterol biosynthesis, are mainstays of hyperlipidemia therapy in humans with risk factors for atherosclerosis [112]. Studies in a mouse model of sickle cell disease (SCD) suggested that one such drug, Simvastatin, protected host cells from the cytotoxic effects of PLY and other CDCs, including SLO and tetanolysin, a finding suggested to reflect the requirement of cholesterol for efficient pore formation and cytotoxicity [113]. Human airway epithelial cells treated with physiological serum concentration ranges of simvastatin in vitro also confirmed protection against PLY and Hla cytotoxicity, but this finding was not shared in other cell lines tested [114]. Since statins are known to have other pleiotrophic and immunomodulatory effects on cells, further experimentation with these drugs and other cholesterol-modifying agents in the context of $\beta$-PFTs is warranted. In this way, a mechanistic framework can be elucidated and inform potential therapeutic avenues.

\section{Blockade of Pore Formation}

Once the $\beta$-PFT has oligomerized and been inserted into the host cell membrane, the pores that are formed have a characteristic size and shape depending on the particular toxin inducing the damage [115]. The pore becomes a permeable channel and pathway for the flux of ions and other charged or polar molecules to cross the plasma membrane, which can alter host downstream signaling cascades at sub-cytolytic levels, or at higher doses provoke complete cell lysis [5-7,116-118]. Considering this deceptively simple shared outcome of $\beta$-PFT action, i.e., the creation of a membrane hole, a potential approach to counteract this insult arises in the direct physical obstruction or "plugging" of the hole $[119,120]$.

One method that has been explored to block oligomeric pores is the use of cyclodextrins, cyclic oligomers of glucose that form water-soluble inclusion complexes with small and large molecules in a variety of biotechnology applications [121]. Selectively blockade of $S$. aureus Hla using $\beta$-cyclodextrin derivatives demonstrated that symmetry, size of the inhibitor and pore size are all important factors in determining efficacy [122,123]. For example, only $\beta$-cyclodextrin derivatives, and not $\alpha$ - or $\gamma$-derivatives, effectively inhibited Hla by mirroring the symmetry of the heptameric toxin. In other studies, the $\beta$-cyclodextrin derivative IB201 (ANBO $\beta C D$ ) blocked Hla channels irreversibly [123], and were reported to block the assembled Hla pore and decrease mortality in a murine model of S. aureus pneumonia [124]. A slightly different approach showed that two different salts of an isatin-Schiff base copper(II) complex, $\mathrm{Cu}$ (isapn), with perclorate- $[\mathrm{Cu}($ isapn $)]\left(\mathrm{ClO}_{4}\right)_{2}$ - or sulfonate- $[\mathrm{Cu}$ (isapn) $]\left(\mathrm{SO}_{4}\right)_{2}$, had significant anti-Hla activity by interacting with the constriction region of the pore and blocking it in an electrical potential-dependent manner [125]. Finally, a high-throughput screening of a 151,616-compound library identified three compounds, N-cycloalkylbenzamide, furo[2,3-b]quinoline, and $6 \mathrm{H}$-anthra[1,9-cd]isoxazol, that appeared to inhibit $C$. perfringens Etx toxin by blocking the active pore, since cytotoxicity was reduced without direct toxin binding or interference with the toxin oligomerization process [126].

\section{Increasing Host Cell Resiliency Against Pore-Forming Toxin Action}

After attack by a PFT, the host cell can respond to this insult through several mechanisms that depend upon the type and concentration of the PFT, as well as the nature of the host cell(s) affected, since both factors differentially influence downstream stress response pathways and signaling events [8]. Although high concentrations of PFTs may cause wholescale host cell lysis, at lower toxin concentrations, survival of intoxicated cells is well documented and reviewed $[6,8,127]$. Understanding 
the specific mechanisms by which the host cell resists PFT damage can reveal new targets for pharmacological intervention.

Resealing of the membrane pore through regulation of membrane lipids, control of cytoskeletal dynamics, enhancement of blebbing and microvesicle shedding are some of the attractive options for further investigation [128-131]. For example, the decrease in cytoplasmic potassium after pore formation promotes inflammasome activation through caspase-1, leading to maturation of the important pro-immune and pro-inflammatory cytokine IL-1 $\beta$ to combat infection. This same potassium efflux influences lipid membrane biogenesis gene regulator sterol regulatory element binding protein 1 (SREBP1), a key orchestrator of membrane repair processes [132]. Another study reported that the pretreatment of lung epithelial cells with interferon-alpha (IFN- $\alpha$ ) prior to challenge with $S$. aureus Hla prevents cell-death by modifying lipid metabolism and increasing protein synthesis and fatty acid activity, noting that these changes were independent of caspase- 1 or mitogen-activated protein kinases [133].

A key virulence attribute of PLY is its ability to impair pulmonary barrier function by disrupting epithelial tight junction integrity to increase alveolar permeability [134]. A recent study revealed two peptides derived from host mediators that may counteract these negative effects of PLY. First, growth hormone-releasing hormone (GHRH) agonist JI-34 was found to enhance epithelial sodium channel $(\mathrm{ENaC})$ function and capillary resistance in a cAMP-dependent manner [135]. Secondly, the TNF $\alpha$-derived TIP peptide AP301, currently in phase 2a clinical trials, blunted activation of the enzymes protein kinase C- $\alpha$ and arginase 1 , which induce hyperpermeability of the capillary endothelium following PLY exposure, both in vitro and in an in vivo mouse model [135].

A screen in the roundworm Caenorhabditis elegans for mutants resistant to the PFT crystal protein (Cry) revealed that induction of hypoxia-inducible factor-1 (HIF-1), a transcription factor expressed by all metazoan species and master regulator of oxygen homeostasis [136], can protect cells against cytotoxicity [137]. HIF induces the transcription of genes involved in the innate immune response such as IL-1 $\beta$, IL-8, TNF $\alpha$, iNOS and the antimicrobial peptide cathelicidin LL-37, which could explain the enhanced survival after PFT intoxication [138]. Under normoxic conditions, HIF is hydroxylated by prolyl hydroxylases (PHDs) and consequently degraded by a ubiquitin-ligase complex in the host cell proteosome [139]. AKB-4924 (Akebia Therapeutics), a PHD inhibitor that stabilizes HIF-1 levels and increases cutaneous innate defense against S. aureus infections [140], and it is conceivable that protection against $\mathrm{Hla}$, a major virulence factor during skin infection, contributes significantly to the drug's pharmacological efficacy.

Recently, high-throughput genetic screens in human cells have been deployed to discover novel host factors required for bacterial PFT toxicity [141,142]. Insertional mutagenesis screens in human haploid cells coupled to validation by CRISPR-Cas9 gene deletion studies revealed plekstrin-homology domain containing protein 7 (PLEKHA7) to be a novel mediator of Hla cytotoxicity [143]. Another gene-trap mutagenesis and RNA interference study concluded that Etx was capable of binding to the hepatitis A virus cellular receptor 1 (HAVCR1), providing new insights into the process of toxin-induced cell death [144] Finally, a host cellular defense mechanism suggested as a potential therapeutic target to protect against PFT injury is autophagy, a lysosomal process involved in maintaining cellular homeostasis through turnover of damaged or redundant proteins and organelles [145], which in its extreme form can result in autophagic cell death [146]. Numerous bacterial pathogens interfere with the autophagy process, but the interaction between autophagy and bacteria often depends on the type of bacteria and the type of PFT they secrete [146,147]. A review of selected FDA-approved drugs and pharmacological agents that modulate autophagy and could help improve the outcome of antibiotic treatment can be found here [148].

\section{Inactivated PFT (Toxoid) Vaccines for Active Immunization}

Knowledge derived from decades of studying PFT structure and pore architecture by x-ray crystallography and other structural biochemistry methods has informed the design of inactivated 
(toxoid) vaccines to prime the host immune system without inducing the deleterious effects of the PFT itself $[6,149]$. Pneumococcal polysaccharide conjugate vaccines, including the 7- and 13-valent forms of Prevnar and the 23-valent Pneumovax, have dramatically decreased the burden of severe disease in many populations [150]. However, development of broader protection among more than 90 serotypes of pneumococcus is desirable due to ongoing shifts in serotype epidemiology. For this reason, the highly conserved PLY has been regarded as an attractive protein antigen vaccine candidate $[149,151,152]$. Pneumolysin toxoid (dPly), formulated with another pneumococcal protein histidine-triad protein $\mathrm{D}(\mathrm{PhtD})$, provided protection against pneumococcal infection after active immunization in animal models [153-155]. Further phase I clinical trials in adults and toddlers showed that dPly + PhtD vaccine formulations were well tolerated and immunogenic when administered as standalone protein vaccines or combined with capsule polysaccharide conjugates [152,153,156]. Another promising PLY toxoid candidate is generated by deletion of alanine 146 and arginine 147 in the pore-forming region ( $\triangle \mathrm{A} 146 \mathrm{PLY}$ ) [157], which does not produce an unwanted pro-inflammatory response in neutrophils [158]. Finally, a fusion protein created using L460D, a noncytolytic PLY toxoid incapable of binding cholesterol [159], when formulated together with conserved choline-binding protein A $(\mathrm{CbpA})$, was broadly protective against pneumococcal infection, with the potential for additional defense against other meningeal pathogens expressing CbpA-like proteins [160].

In a murine model of $S$. aureus pneumonia, immunization with an Hla mutant possessing a single amino acid substitution $\left(\mathrm{Hla}_{\mathrm{H} 35 \mathrm{~L}}\right.$ ) led to decreasing burden and overall mortality upon challenge with the pathogen [52]. Similar protection following $\mathrm{Hla}_{\mathrm{H} 35 \mathrm{~L}}$ vaccination was observed with reduced lesion size in a necrotizing skin infection model [53]. Reasoning that a single point mutation in Hla might not be considered ideally safe for use in a clinical setting, additional truncation mutant forms of the toxin have been evaluated as vaccine candidates using structure-based approach. Based on molecular modeling, a lead Hla vaccine candidate (AT-62aa) exhibited strong immunogenicity in mice when used with two clinically validated adjuvants $\left(\mathrm{AlPO}_{4}\right.$ and GLA-SE) in models of S. aureus skin and soft tissue infections [161,162]. A chimeric bivalent vaccine using inactivated Hla and S. aureus iron surface determinant $\mathrm{B}$ (IsdB) has a stronger protective immune response than either protein alone [163]. Attenuated subunit vaccines using mutant forms of PFTs LukS-PV and LukF-PV subunits LukS-Mut9/LukF-Mut1 were highly immunogenic and demonstrate significant protection against $S$. aureus sepsis [64].

Certain noncytolytic LLO mutants (LLO W492A and LLO W491-492A) maintain binding capacity to the cell membranes with high affinity and are catabolized, processed, and presented efficiently by APCs to CD4+ or CD8+ T cells [164-166], although LLO is known to be strongly immunogenic, independent of its cytotoxicity [165], and its role has been explored more extensively in the context of live vaccine vectors [167]. Initial studies on C. perfringens Epsilon toxin (Etx) determined that the H149A mutation (Etx-H149A) could reduce, yet not abolish, toxicity [168], and inspired evaluation of the site-directed Etx mutant (Y30A-Y196A) as a potential recombinant vaccine antigen component. In vitro, Etx (Y30A-Y196A) significantly reduced cell binding and cytotoxic activities in MDCK.2 cells [72]. Studies on S. pyogenes SLO showed that a recombinant SLO derivate (rSLOmut) with mutated tryptophan residue in the membrane-binding loop W535A elicits protective immunity against lethal GAS challenge $[169,170]$.

In a recent effort to maximize PFT vaccine potency and safety, alternative strategies employing non-denatured PFTs anchored to the aforementioned RBC membrane-coated nanoparticles have been explored. These "nanotoxoids" harboring Hla were capable of bestowing strong protective immunity in a murine lethal intoxication model with the native virulence factor $[171,172]$. The nanotoxoid vaccines were efficiently cleared with no additional toxicity after a period of two weeks and could potentially be used for a broad range of PFTs simultaneously in a multiplexed format, ultimately finding their way to the clinic using O-negative donor blood (or the patient's own blood). 


\section{Conclusions}

While the contribution of PFTs to the establishment and severity of many leading bacterial infectious disease has long been appreciated, significant steps to exploit this knowledge to improve patient outcomes is limited to proof-of-principle investigations with target cell lines, preclinical-stage in vivo studies in small animal models, and a few early clinical studies, predominantly in the realm of monoclonal anti-PFT antibodies. This review cites intriguing evidence that disarming bacterial pathogens through inhibition of their $\beta$-PFTs at various stages of secretion or host cell interaction (Table 1) could ameliorate disease pathology and constitute a viable adjunctive treatment option when classical antibiotics and supportive care fail to achieve rapid resolution. In and of themselves, PFT-neutralizing drugs would spare the normal microbiome from depletion associated with broad-spectrum antibiotic therapy, increasingly seen as an aggravating risk factor for many chronic inflammatory or autoimmune diseases. More detailed structure-function analysis of leading PFTs, coupled with a mechanistic understanding of the host cell stress response pathways they induce, can inform the optimal design and discovery of new agents in this class.

Table 1. Potential therapeutic approaches to inactivate bacterial pore-forming toxins.

\begin{tabular}{|c|c|c|c|c|}
\hline $\begin{array}{c}\text { General } \\
\text { Mechanism }\end{array}$ & Subclassification & PFT & Therapeutic Concept or Candidate & References \\
\hline \multirow{11}{*}{$\begin{array}{l}\text { Direct Binding } \\
\text { and Inhibition }\end{array}$} & \multirow{5}{*}{$\begin{array}{c}\text { Passive } \\
\text { Immunization } \\
\text { with Monoclonal } \\
\text { Antibodies }\end{array}$} & S. aureus $\alpha$-toxin (Hla) & $\begin{array}{l}\text { mAbs MEDI4893, (MedImmune), LTM14. } \\
\text { A3 and LC10, 7B8 and 1A9. }\end{array}$ & {$[52-61]$} \\
\hline & & $\begin{array}{c}\text { LukS-PV, LukF-PV, } \\
\gamma \text {-hemolysin C (HlgC) }\end{array}$ & $\begin{array}{c}\text { AR-301 (Salvecin }{ }^{\mathrm{TM}} \text { ) ASN-1 and ASN-2. } \\
\text { ASN100 (Arsanis) }\end{array}$ & {$[62-67]$} \\
\hline & & S. aureus leukotoxins & Heavy chain-only antibodies & [68] \\
\hline & & Pneumolysin (PLY) & mAbs PLY 4 PLY 7 & {$[69,70]$} \\
\hline & & Anthrolysin O (ALO) & mAbs $64 \mathrm{~F} 8$ and $80 \mathrm{C} 9$ & {$[71]$} \\
\hline & \multirow{4}{*}{$\begin{array}{l}\text { Small Molecules } \\
\text { that Bind or } \\
\text { Inhibit Toxin } \\
\text { Assembly }\end{array}$} & S. aureus $\alpha$-toxin (Hla) & $\begin{array}{l}\text { Baicalin, quercetin, trans-reservertrol, } \\
\text { betulinic acid, orolyxins and other } \\
\text { flavonoids, peptide IYGSKANRQTDK }\end{array}$ & [76-80] \\
\hline & & Pneumolysin (PLY) & $\begin{array}{c}\beta \text {-sitosterol, apigenin, amentoflavone, } \\
\text { verbascoside }\end{array}$ & [81-84] \\
\hline & & Streptolysin O (SLO) & Allicin, lacto- $N$-neotetraose & {$[85,86]$} \\
\hline & & Listeriolysin O (LLO) & Finestin, RD-1 & {$[87,88]$} \\
\hline & \multirow[t]{2}{*}{ Decoy Capture } & $\begin{array}{l}\text { Hla, PLY, and potentially } \\
\text { broad-spectrum }\end{array}$ & $\begin{array}{c}(\mathrm{Ch}: \mathrm{Sm}) \text { liposomes, }(\mathrm{Ch}: \mathrm{Sm}+\mathrm{Sm}) \\
\text { liposomes, CAL02 (Combioxin SA) }\end{array}$ & [91] \\
\hline & & $\begin{array}{l}\text { HLa, SLO, and potentially } \\
\text { broad spectrum }\end{array}$ & Biomimetic RBC-coated nanoparticles & {$[95-99]$} \\
\hline \multirow{2}{*}{$\begin{array}{l}\text { Inhibition of } \\
\text { Host Cell }\end{array}$} & \multirow{2}{*}{$\begin{array}{l}\text { Small Molecules, } \\
\text { Drug }\end{array}$} & S. aureus $\alpha$-toxin (Hla) & GI254023X (ADAM10 inhibitor) & [101-103] \\
\hline & & Intermediolysin (ILY) & ILY peptide, rILYd4 & {$[108,109]$} \\
\hline \multirow{3}{*}{$\begin{array}{l}\text { Receptors or } \\
\text { Uptake } \\
\text { Mechanisms }\end{array}$} & \multirow{3}{*}{$\begin{array}{l}\text { Repurposing, } \\
\text { Peptides and } \\
\text { Antibodies }\end{array}$} & S. aureus LeukED & Maraviroc (CCR5 agonist) & {$[104,105]$} \\
\hline & & Pneumolysin (PLY) & Anti-LeX/sLeX antibodies & [86] \\
\hline & & PLY, SLO, tetanolysin & Simvastatin & {$[113,114]$} \\
\hline \multirow{2}{*}{$\begin{array}{l}\text { Blockade of } \\
\text { Pore Formation }\end{array}$} & \multirow[t]{2}{*}{ Small Molecules } & S. aureus $\alpha$-toxin (Hla) & $\begin{array}{l}\beta \text {-cyclodextrins, isatin-Schiff base copper } \\
\text { (II) complex }\end{array}$ & {$[122-125]$} \\
\hline & & Clostridium perfringens Etx & $\begin{array}{l}\text { Specific quinoline and isoxazol } \\
\text { compounds }\end{array}$ & [126] \\
\hline \multirow{4}{*}{$\begin{array}{l}\text { Increase Host } \\
\text { Cell Resiliency } \\
\text { Against PFT }\end{array}$} & \multirow{4}{*}{$\begin{array}{l}\text { Stimulate } \\
\text { Membrane Repair } \\
\text { Pathways }\end{array}$} & Pneumolysin (PLY) & $\begin{array}{c}\text { AP301 TNF } \alpha \text {-derived TIP peptide, JI-34 } \\
\text { GHRH agonist }\end{array}$ & {$[134,135]$} \\
\hline & & S. aureus $\alpha$-toxin (Hla) & IFN- $\alpha$ (increase in lipid metabolism) & [133] \\
\hline & & S. aureus $\alpha$-toxin (Hla)? & HIF-1 stabilizing PHD inhibitor, AKB4923 & {$[137,140]$} \\
\hline & & Pneumolysin (PLY) & $\begin{array}{c}\text { Toxoid dPly, } \Delta 6 \text { PLY, peptide-L460D } \\
\text { "pneumolysoid" }\end{array}$ & {$[153-160]$} \\
\hline \multirow{6}{*}{$\begin{array}{l}\text { Active } \\
\text { Immunization }\end{array}$} & \multirow{6}{*}{$\begin{array}{l}\text { Inactivated PFT } \\
\text { (Toxoid) Vaccines }\end{array}$} & S. aureus $\alpha$-toxin (Hla) & $\begin{array}{c}\text { Hla }_{\mathrm{H} 35 \mathrm{~L}}, \mathrm{AT} 62, \text { chimeric bivalent } \\
\text { IsdB/Hla }\end{array}$ & $\begin{array}{c}{[52,53]} \\
{[161-163]}\end{array}$ \\
\hline & & $\begin{array}{l}\text { Hla, possibly } \\
\text { broad-spectrum }\end{array}$ & RBC "nanotoxoids" with absorbed PFTs & {$[171,172]$} \\
\hline & & $\begin{array}{l}\text { S. aureus LukS-PV, } \\
\text { LukF-PV }\end{array}$ & LukS-Mut9/LukF-Mut1 & {$[64]$} \\
\hline & & Streptolysin O (SLO) & Inactivated W535A toxoid & {$[169,170]$} \\
\hline & & Clostridium perfringens Etx & Y30A-Y196A toxoid & {$[72,168]$} \\
\hline & & Listeriolysin O (LLO) & LLO W492A, LLO W491-492A toxoid & [164-166] \\
\hline
\end{tabular}


Author Contributions: Conceptualization, T.E. and V.N.; Data Curation, T.E. and V.N.; Writing-Original Draft Preparation, T.E.; Writing-Review \& Editing, V.N.

Funding: This work was supported by the National Institutes of Health under Award Numbers R01AI077780 (V.N.), and R01HL125352 (V.N.). T.E. was supported through the UCSD NIH/NIGMS Training Program in Molecular and Cellular Pharmacology (T32GM007752) and PhRMA Foundation Fellowship.

Conflicts of Interest: The authors declare no conflict of interest.

\section{References}

1. Alanis, A.J. Resistance to antibiotics: Are we in the post-antibiotic era? Arch. Med. Res. 2005, 36, $697-705$. [CrossRef] [PubMed]

2. Boucher, H.W.; Talbot, G.H.; Bradley, J.S.; Edwards, J.E.; Gilbert, D.; Rice, L.B.; Scheld, M.; Spellberg, B.; Bartlett, J. Bad bugs, no drugs: No ESKAPE! An update from the Infectious Diseases Society of America. Clin. Infect. Dis. 2009, 48, 1-12. [CrossRef] [PubMed]

3. Spellberg, B.; Guidos, R.; Gilbert, D.; Bradley, J.; Boucher, H.W.; Scheld, W.M.; Bartlett, J.G.; Edwards, J., Jr. The epidemic of antibiotic-resistant infections: A call to action for the medical community from the Infectious Diseases Society of America. Clin. Infect. Dis. 2008, 46, 155-164. [CrossRef] [PubMed]

4. Gonzalez, M.R.; Bischofberger, M.; Pernot, L.; van der Goot, F.G.; Freche, B. Bacterial pore-forming toxins: The (w)hole story? Cell. Mol. Life Sci. 2008, 65, 493-507. [CrossRef] [PubMed]

5. Los, F.C.; Randis, T.M.; Aroian, R.V.; Ratner, A.J. Role of pore-forming toxins in bacterial infectious diseases. Microbiol. Mol. Biol. Rev. 2013, 77, 173-207. [CrossRef]

6. Dal Peraro, M.; van der Goot, F.G. Pore-forming toxins: Ancient, but never really out of fashion. Nat. Rev. Microbiol. 2016, 14, 77-92. [CrossRef]

7. Kao, C.Y.; Los, F.C.; Huffman, D.L.; Wachi, S.; Kloft, N.; Husmann, M.; Karabrahimi, V.; Schwartz, J.L.; Bellier, A.; Ha, C.; et al. Global functional analyses of cellular responses to pore-forming toxins. PLoS Pathog. 2011, 7, e1001314. [CrossRef]

8. Bischofberger, M.; Iacovache, I.; van der Goot, F.G. Pathogenic pore-forming proteins: Function and host response. Cell Host Microbe 2012, 12, 266-275. [CrossRef]

9. Tweten, R.K. Cholesterol-dependent cytolysins, a family of versatile pore-forming toxins. Infect. Immun. 2005, 73, 6199-6209. [CrossRef]

10. Griffitts, J.S.; Haslam, S.M.; Yang, T.; Garczynski, S.F.; Mulloy, B.; Morris, H.; Cremer, P.S.; Dell, A.; Adang, M.J.; Aroian, R.V. Glycolipids as receptors for Bacillus thuringiensis crystal toxin. Science 2005, 307, 922-925. [CrossRef]

11. Giddings, K.S.; Zhao, J.; Sims, P.J.; Tweten, R.K. Human CD59 is a receptor for the cholesterol-dependent cytolysin intermedilysin. Nat. Struct. Mol. Biol. 2004, 11, 1173-1178. [CrossRef]

12. Diep, D.B.; Nelson, K.L.; Raja, S.M.; Pleshak, E.N.; Buckley, J.T. Glycosylphosphatidylinositol anchors of membrane glycoproteins are binding determinants for the channel-forming toxin aerolysin. J. Biol. Chem. 1998, 273, 2355-2360. [CrossRef]

13. Muhlen, S.; Dersch, P. Anti-virulence Strategies to Target Bacterial Infections. Curr. Top. Microbiol. Immunol. 2016, 398, 147-183.

14. Rasko, D.A.; Sperandio, V. Anti-virulence strategies to combat bacteria-mediated disease. Nat. Rev. Drug Discov. 2010, 9, 117-128. [CrossRef] [PubMed]

15. Clatworthy, A.E.; Pierson, E.; Hung, D.T. Targeting virulence: A new paradigm for antimicrobial therapy. Nat. Chem. Biol. 2007, 3, 541-548. [CrossRef]

16. Gouaux, E. Channel-forming toxins: Tales of transformation. Curr. Opin. Struct. Biol. 1997, 7, $566-573$. [CrossRef]

17. Parker, M.W.; Feil, S.C. Pore-forming protein toxins: From structure to function. Prog. Biophys. Mol. Biol. 2005, 88, 91-142. [CrossRef] [PubMed]

18. Rojko, N.; Kristan, K.C.; Viero, G.; Zerovnik, E.; Macek, P.; Dalla Serra, M.; Anderluh, G. Membrane damage by an alpha-helical pore-forming protein, Equinatoxin II, proceeds through a succession of ordered steps. J. Biol. Chem. 2013, 288, 23704-23715. [CrossRef] [PubMed]

19. Cascales, E.; Buchanan, S.K.; Duche, D.; Kleanthous, C.; Lloubes, R.; Postle, K.; Riley, M.; Slatin, S.; Cavard, D. Colicin biology. Microbiol. Mol. Biol. Rev. 2007, 71, 158-229. [CrossRef] 
20. Lakey, J.H.; van der Goot, F.G.; Pattus, F. All in the family: The toxic activity of pore-forming colicins. Toxicology 1994, 87, 85-108. [CrossRef]

21. Parker, M.W.; Pattus, F.; Tucker, A.D.; Tsernoglou, D. Structure of the membrane-pore-forming fragment of colicin A. Nature 1989, 337, 93-96. [CrossRef] [PubMed]

22. Grochulski, P.; Masson, L.; Borisova, S.; Pusztai-Carey, M.; Schwartz, J.L.; Brousseau, R.; Cygler, M. Bacillus thuringiensis CryIA(a) insecticidal toxin: Crystal structure and channel formation. J. Mol. Biol. 1995, 254, 447-464. [CrossRef] [PubMed]

23. Choe, S.; Bennett, M.J.; Fujii, G.; Curmi, P.M.; Kantardjieff, K.A.; Collier, R.J.; Eisenberg, D. The crystal structure of diphtheria toxin. Nature 1992, 357, 216. [CrossRef] [PubMed]

24. Allured, V.S.; Collier, R.J.; Carroll, S.F.; McKay, D.B. Structure of exotoxin A of Pseudomonas aeruginosa at 3.0-Angstrom resolution. Proc. Natl. Acad. Sci. USA 1986, 83, 1320-1324. [CrossRef] [PubMed]

25. Ros, U.; Garcia-Saez, A.J. More Than a Pore: The Interplay of Pore-Forming Proteins and Lipid Membranes. J. Membr. Biol. 2015, 248, 545-561. [CrossRef] [PubMed]

26. Walker, B.; Bayley, H. Key residues for membrane binding, oligomerization, and pore forming activity of staphylococcal alpha-hemolysin identified by cysteine scanning mutagenesis and targeted chemical modification. J. Biol. Chem. 1995, 270, 23065-23071. [CrossRef] [PubMed]

27. Tilley, S.J.; Saibil, H.R. The mechanism of pore formation by bacterial toxins. Curr. Opin. Struct. Biol. 2006, 16, 230-236. [CrossRef]

28. Tweten, R.K.; Parker, M.W.; Johnson, A.E. The cholesterol-dependent cytolysins. Curr. Top. Microbiol. Immunol. 2001, 257, 15-33.

29. Palmer, M.; Harris, R.; Freytag, C.; Kehoe, M.; Tranum-Jensen, J.; Bhakdi, S. Assembly mechanism of the oligomeric streptolysin O pore: The early membrane lesion is lined by a free edge of the lipid membrane and is extended gradually during oligomerization. EMBO J. 1998, 17, 1598-1605. [CrossRef]

30. Sowdhamini, R.; Mitchell, T.J.; Andrew, P.W.; Morgan, P.J. Structural and functional analogy between pneumolysin and proaerolysin. Protein Eng. 1997, 10, 207-215. [CrossRef]

31. Macey, M.G.; Whiley, R.A.; Miller, L.; Nagamune, H. Effect on polymorphonuclear cell function of a human-specific cytotoxin, intermedilysin, expressed by Streptococcus intermedius. Infect. Immun. 2001, 69, 6102-6109. [CrossRef] [PubMed]

32. Geoffroy, C.; Gaillard, J.L.; Alouf, J.E.; Berche, P. Production of thiol-dependent haemolysins by Listeria monocytogenes and related species. J. Gen. Microbiol. 1989, 135, 481-487. [CrossRef] [PubMed]

33. Mengaud, J.; Vicente, M.F.; Chenevert, J.; Pereira, J.M.; Geoffroy, C.; Gicquel-Sanzey, B.; Baquero, F.; Perez-Diaz, J.C.; Cossart, P. Expression in Escherichia coli and sequence analysis of the listeriolysin O determinant of Listeria monocytogenes. Infect. Immun. 1988, 56, 766-772. [PubMed]

34. Shannon, J.G.; Ross, C.L.; Koehler, T.M.; Rest, R.F. Characterization of anthrolysin O, the Bacillus anthracis cholesterol-dependent cytolysin. Infect. Immun. 2003, 71, 3183-3189. [CrossRef]

35. Rossjohn, J.; Feil, S.C.; McKinstry, W.J.; Tweten, R.K.; Parker, M.W. Structure of a cholesterol-binding, thiol-activated cytolysin and a model of its membrane form. Cell 1997, 89, 685-692. [CrossRef]

36. Parker, M.W.; Buckley, J.T.; Postma, J.P.; Tucker, A.D.; Leonard, K.; Pattus, F.; Tsernoglou, D. Structure of the Aeromonas toxin proaerolysin in its water-soluble and membrane-channel states. Nature 1994, 367, $292-295$. [CrossRef]

37. Song, L.; Hobaugh, M.R.; Shustak, C.; Cheley, S.; Bayley, H.; Gouaux, J.E. Structure of staphylococcal alpha-hemolysin, a heptameric transmembrane pore. Science 1996, 274, 1859-1866. [CrossRef] [PubMed]

38. Rojko, N.; Anderluh, G. How lipid membranes affect pore forming toxin activity. Acc. Chem. Res. 2015, 48, 3073-3079. [CrossRef]

39. Iacovache, I.; van der Goot, F.G.; Pernot, L. Pore formation: An ancient yet complex form of attack. Biochim. Biophys. Acta 2008, 1778, 1611-1623. [CrossRef] [PubMed]

40. Parker, M.W. Cryptic clues as to how water-soluble protein toxins form pores in membranes. Toxicon 2003, 42, 1-6. [CrossRef]

41. Sonnen, A.F.; Henneke, P. Role of pore-forming toxins in neonatal sepsis. Clin. Dev. Immunol. 2013, 2013, 608456. [CrossRef]

42. Mulvihill, E.; van Pee, K.; Mari, S.A.; Muller, D.J.; Yildiz, O. Directly observing the lipid-dependent self-assembly and pore-forming mechanism of the cytolytic toxin listeriolysin O. Nano Lett. 2015, 15, 6965-6973. [CrossRef] [PubMed] 
43. Van Pee, K.; Neuhaus, A.; D’Imprima, E.; Mills, D.J.; Kuhlbrandt, W.; Yildiz, O. CryoEM structures of membrane pore and prepore complex reveal cytolytic mechanism of pneumolysin. eLife 2017, 6, e23644. [CrossRef] [PubMed]

44. Yilmaz, N.; Yamaji-Hasegawa, A.; Hullin-Matsuda, F.; Kobayashi, T. Molecular mechanisms of action of sphingomyelin-specific pore-forming toxin, lysenin. Semin. Cell Dev. Biol. 2018, 73, 188-198. [CrossRef] [PubMed]

45. Leone, P.; Bebeacua, C.; Opota, O.; Kellenberger, C.; Klaholz, B.; Orlov, I.; Cambillau, C.; Lemaitre, B.; Roussel, A. X-ray and Cryo-electron microscopy structures of monalysin pore-forming toxin reveal multimerization of the pro-form. J. Biol. Chem. 2015, 290, 13191-13201. [CrossRef] [PubMed]

46. Iacovache, I.; De Carlo, S.; Cirauqui, N.; Dal Peraro, M.; van der Goot, F.G.; Zuber, B. Cryo-EM structure of aerolysin variants reveals a novel protein fold and the pore-formation process. Nat. Commun. 2016, 7, 12062. [CrossRef] [PubMed]

47. Boyd, C.M.; Parsons, E.S.; Smith, R.A.; Seddon, J.M.; Ces, O.; Bubeck, D. Disentangling the roles of cholesterol and CD59 in intermedilysin pore formation. Sci. Rep. 2016, 6, 38446. [CrossRef]

48. Chames, P.; Van Regenmortel, M.; Weiss, E.; Baty, D. Therapeutic antibodies: Successes, limitations and hopes for the future. Br. J. Pharmacol. 2009, 157, 220-233. [CrossRef]

49. DiGiandomenico, A.; Sellman, B.R. Antibacterial monoclonal antibodies: The next generation? Curr. Opin. Microbiol. 2015, 27, 78-85. [CrossRef]

50. Lang, A.B.; Cryz, S.J., Jr.; Schurch, U.; Ganss, M.T.; Bruderer, U. Immunotherapy with human monoclonal antibodies. Fragment A specificity of polyclonal and monoclonal antibodies is crucial for full protection against tetanus toxin. J. Immunol. 1993, 151, 466-472.

51. Khazaeli, M.B.; Conry, R.M.; LoBuglio, A.F. Human immune response to monoclonal antibodies. J. Immunother. Emphas. Tumor Immunol. 1994, 15, 42-52. [CrossRef]

52. Bubeck Wardenburg, J.; Schneewind, O. Vaccine protection against Staphylococcus aureus pneumonia. J. Exp. Med. 2008, 205, 287-294. [CrossRef] [PubMed]

53. Kennedy, A.D.; Bubeck Wardenburg, J.; Gardner, D.J.; Long, D.; Whitney, A.R.; Braughton, K.R.; Schneewind, O.; DeLeo, F.R. Targeting of alpha-hemolysin by active or passive immunization decreases severity of USA300 skin infection in a mouse model. J. Infect. Dis. 2010, 202, 1050-1058. [CrossRef] [PubMed]

54. Francois, B.; Mercier, E.; Gonzalez, C.; Asehnoune, K.; Nseir, S.; Fiancette, M.; Desachy, A.; Plantefeve, G.; Meziani, F.; de Lame, P.A.; et al. Safety and tolerability of a single administration of AR-301, a human monoclonal antibody, in ICU patients with severe pneumonia caused by Staphylococcus aureus: First-in-human trial. Intensive Care Med. 2018, 44, 1787-1796. [CrossRef] [PubMed]

55. Foletti, D.; Strop, P.; Shaughnessy, L.; Hasa-Moreno, A.; Casas, M.G.; Russell, M.; Bee, C.; Wu, S.; Pham, A.; Zeng, Z.; et al. Mechanism of action and in vivo efficacy of a human-derived antibody against Staphylococcus aureus alpha-hemolysin. J. Mol. Biol. 2013, 425, 1641-1654. [CrossRef]

56. Oganesyan, V.; Peng, L.; Damschroder, M.M.; Cheng, L.; Sadowska, A.; Tkaczyk, C.; Sellman, B.R.; Wu, H.; Dall'Acqua, W.F. Mechanisms of neutralization of a human anti-alpha-toxin antibody. J. Biol. Chem. 2014, 289, 29874-29880. [CrossRef]

57. Hua, L.; Cohen, T.S.; Shi, Y.; Datta, V.; Hilliard, J.J.; Tkaczyk, C.; Suzich, J.; Stover, C.K.; Sellman, B.R. MEDI4893* Promotes survival and extends the antibiotic treatment window in a Staphylococcus aureus immunocompromised pneumonia model. Antimicrob. Agents Chemother. 2015, 59, 4526-4532. [CrossRef]

58. Yu, X.Q.; Robbie, G.J.; Wu, Y.; Esser, M.T.; Jensen, K.; Schwartz, H.I.; Bellamy, T.; Hernandez-Illas, M.; Jafri, H.S. Safety, tolerability, and pharmacokinetics of MEDI4893, an investigational, extended-half-life, anti-Staphylococcus aureus alpha-toxin human monoclonal antibody, in healthy adults. Antimicrob. Agents Chemother. 2017, 6, e01020-16. [CrossRef]

59. Tkaczyk, C.; Hua, L.; Varkey, R.; Shi, Y.; Dettinger, L.; Woods, R.; Barnes, A.; MacGill, R.S.; Wilson, S.; Chowdhury, P.; et al. Identification of anti-alpha toxin monoclonal antibodies that reduce the severity of Staphylococcus aureus dermonecrosis and exhibit a correlation between affinity and potency. Clin. Vaccine Immunol. 2012, 19, 377-385. [CrossRef]

60. Hua, L.; Hilliard, J.J.; Shi, Y.; Tkaczyk, C.; Cheng, L.I.; Yu, X.; Datta, V.; Ren, S.; Feng, H.; Zinsou, R.; et al. Assessment of an anti-alpha-toxin monoclonal antibody for prevention and treatment of Staphylococcus aureus-induced pneumonia. Antimicrob. Agents Chemother. 2014, 58, 1108-1117. [CrossRef] 
61. Ragle, B.E.; Bubeck Wardenburg, J. Anti-alpha-hemolysin monoclonal antibodies mediate protection against Staphylococcus aureus pneumonia. Infect. Immun. 2009, 77, 2712-2718. [CrossRef] [PubMed]

62. Seilie, E.S.; Bubeck Wardenburg, J. Staphylococcus aureus pore-forming toxins: The interface of pathogen and host complexity. Semin. Cell Dev. Biol. 2017, 72, 101-116. [CrossRef]

63. Alonzo, F., 3rd; Torres, V.J. The bicomponent pore-forming leucocidins of Staphylococcus aureus. Microbiol. Mol. Biol. Rev. 2014, 78, 199-230. [CrossRef] [PubMed]

64. Karauzum, H.; Adhikari, R.P.; Sarwar, J.; Devi, V.S.; Abaandou, L.; Haudenschild, C.; Mahmoudieh, M.; Boroun, A.R.; Vu, H.; Nguyen, T.; et al. Structurally designed attenuated subunit vaccines for S. aureus LukS-PV and LukF-PV confer protection in a mouse bacteremia model. PLoS ONE 2013, 8, e65384. [CrossRef] [PubMed]

65. Rouha, H.; Badarau, A.; Visram, Z.C.; Battles, M.B.; Prinz, B.; Magyarics, Z.; Nagy, G.; Mirkina, I.; Stulik, L.; Zerbs, M.; et al. Five birds, one stone: Neutralization of alpha-hemolysin and 4 bi-component leukocidins of Staphylococcus aureus with a single human monoclonal antibody. mAbs 2015, 7, 243-254. [CrossRef]

66. Rouha, H.; Weber, S.; Janesch, P.; Maierhofer, B.; Gross, K.; Dolezilkova, I.; Mirkina, I.; Visram, Z.C.; Malafa, S.; Stulik, L.; et al. Disarming Staphylococcus aureus from destroying human cells by simultaneously neutralizing six cytotoxins with two human monoclonal antibodies. Virulence 2018, 9, 231-247. [CrossRef]

67. Magyarics, Z.; Leslie, F.; Luperchio, S.A.; Bartko, J.; Schörgenhofer, C.; Schwameis, M.; Derhaschnig, U.; Lagler, H.; Stiebellehner, L.; Jilma, B.; et al. Serum and lung pharmacokinetics of ASN100, a monoclonal antibody combination for the prevention and treatment of Staphylococcus aureus pneumonia. Open Forum Infect. Dis. 2017, 4, S310. [CrossRef]

68. Laventie, B.J.; Rademaker, H.J.; Saleh, M.; de Boer, E.; Janssens, R.; Bourcier, T.; Subilia, A.; Marcellin, L.; van Haperen, R.; Lebbink, J.H.; et al. Heavy chain-only antibodies and tetravalent bispecific antibody neutralizing Staphylococcus aureus leukotoxins. Proc. Natl. Acad. Sci. USA 2011, 108, 16404-16409. [CrossRef]

69. Suarez-Alvarez, B.; Garcia-Suarez Mdel, M.; Mendez, F.J.; de los Toyos, J.R. Characterisation of mouse monoclonal antibodies for pneumolysin: Fine epitope mapping and V gene usage. Immunol. Lett. 2003, 88, 227-239. [CrossRef]

70. Garcia-Suarez Mdel, M.; Cima-Cabal, M.D.; Florez, N.; Garcia, P.; Cernuda-Cernuda, R.; Astudillo, A.; Vazquez, F.; De los Toyos, J.R.; Mendez, F.J. Protection against pneumococcal pneumonia in mice by monoclonal antibodies to pneumolysin. Infect. Immun. 2004, 72, 4534-4540. [CrossRef]

71. Nakouzi, A.; Rivera, J.; Rest, R.F.; Casadevall, A. Passive administration of monoclonal antibodies to anthrolysin O prolong survival in mice lethally infected with Bacillus anthracis. BMC Microbiol. 2008, 8, 159. [CrossRef] [PubMed]

72. Bokori-Brown, M.; Hall, C.A.; Vance, C.; Fernandes da Costa, S.P.; Savva, C.G.; Naylor, C.E.; Cole, A.R.; Basak, A.K.; Moss, D.S.; Titball, R.W. Clostridium perfringens epsilon toxin mutant Y30A-Y196A as a recombinant vaccine candidate against enterotoxemia. Vaccine 2014, 32, 2682-2687. [CrossRef] [PubMed]

73. Qiu, J.; Wang, D.; Xiang, H.; Feng, H.; Jiang, Y.; Xia, L.; Dong, J.; Lu, J.; Yu, L.; Deng, X. Subinhibitory concentrations of thymol reduce enterotoxins A and B and alpha-hemolysin production in Staphylococcus aureus isolates. PLoS ONE 2010, 5, e9736. [CrossRef] [PubMed]

74. Shah, S.; Stapleton, P.D.; Taylor, P.W. The polyphenol (-)-epicatechin gallate disrupts the secretion of virulence-related proteins by Staphylococcus aureus. Lett. Appl. Microbiol. 2008, 46, 181-185. [CrossRef] [PubMed]

75. Upadhyay, A.; Mooyottu, S.; Yin, H.; Nair, M.S.; Bhattaram, V.; Venkitanarayanan, K. Inhibiting microbial toxins using plant-derived compounds and plant extracts. Medicines 2015, 2, 186-211. [CrossRef] [PubMed]

76. Qiu, J.; Niu, X.; Dong, J.; Wang, D.; Wang, J.; Li, H.; Luo, M.; Li, S.; Feng, H.; Deng, X. Baicalin protects mice from Staphylococcus aureus pneumonia via inhibition of the cytolytic activity of alpha-hemolysin. J. Infect. Dis. 2012, 206, 292-301. [CrossRef] [PubMed]

77. Cho, H.S.; Lee, J.H.; Cho, M.H.; Lee, J. Red wines and flavonoids diminish Staphylococcus aureus virulence with anti-biofilm and anti-hemolytic activities. Biofouling 2015, 31,1-11. [CrossRef]

78. Dong, J.; Qiu, J.; Zhang, Y.; Lu, C.; Dai, X.; Wang, J.; Li, H.; Wang, X.; Tan, W.; Luo, M.; et al. Oroxylin A inhibits hemolysis via hindering the self-assembly of alpha-hemolysin heptameric transmembrane pore. PLoS Comput. Biol. 2013, 9, e1002869. [CrossRef] 
79. Wang, J.; Zhou, X.; Liu, S.; Li, G.; Shi, L.; Dong, J.; Li, W.; Deng, X.; Niu, X. Morin hydrate attenuates Staphylococcus aureus virulence by inhibiting the self-assembly of alpha-hemolysin. J. Appl. Microbiol. 2015, 118, 753-763. [CrossRef]

80. Rani, N.; Saravanan, V.; Lakshmi, P.T.V.; Annamalai, A. Inhibition of Pore Formation by Blocking the Assembly of Staphylococcus aureus $\alpha$-hemolysin through a novel peptide inhibitor: An in silco approach. Int. J. Peptide Res. Therapeut. 2014, 20, 575-583. [CrossRef]

81. Zhao, X.; Liu, B.; Liu, S.; Wang, L.; Wang, J. Anticytotoxin effects of amentoflavone to pneumolysin. Biol. Pharm. Bull. 2017, 40, 61-67. [CrossRef] [PubMed]

82. Zhao, X.; Li, H.; Wang, J.; Guo, Y.; Liu, B.; Deng, X.; Niu, X. Verbascoside alleviates pneumococcal pneumonia by reducing pneumolysin oligomers. Mol. Pharmacol. 2016, 89, 376-387. [CrossRef] [PubMed]

83. Song, M.; Li, L.; Li, M.; Cha, Y.; Deng, X.; Wang, J. Apigenin protects mice from pneumococcal pneumonia by inhibiting the cytolytic activity of pneumolysin. Fitoterapia 2016, 115, 31-36. [CrossRef] [PubMed]

84. Li, H.; Zhao, X.; Wang, J.; Dong, Y.; Meng, S.; Li, R.; Niu, X.; Deng, X. beta-sitosterol interacts with pneumolysin to prevent Streptococcus pneumoniae infection. Sci. Rep. 2015, 5, 17668. [CrossRef] [PubMed]

85. Arzanlou, M.; Bohlooli, S. Inhibition of streptolysin O by allicin-An active component of garlic. J. Med. Microbiol. 2010, 59, 1044-1049. [CrossRef] [PubMed]

86. Shewell, L.K.; Harvey, R.M.; Higgins, M.A.; Day, C.J.; Hartley-Tassell, L.E.; Chen, A.Y.; Gillen, C.M.; James, D.B.; Alonzo, F., 3rd; Torres, V.J.; et al. The cholesterol-dependent cytolysins pneumolysin and streptolysin $\mathrm{O}$ require binding to red blood cell glycans for hemolytic activity. Proc. Natl. Acad. Sci. USA 2014, 111, E5312-E5320. [CrossRef]

87. Wang, J.; Qiu, J.; Tan, W.; Zhang, Y.; Wang, H.; Zhou, X.; Liu, S.; Feng, H.; Li, W.; Niu, X.; et al. Fisetin inhibits Listeria monocytogenes virulence by interfering with the oligomerization of listeriolysin O. J. Infect. Dis. 2015, 211, 1376-1387. [CrossRef]

88. Ghafari, S.; Komeilian, M.; Hashemi, M.S.; Oushani, S.; Rigi, G.; Rashidieh, B.; Yarahmadi, K.; Khoddam, F. Molecular docking based screening of Listeriolysin-O for improved inhibitors. Bioinformation 2017, 13, 160-163. [CrossRef]

89. Bitounis, D.; Fanciullino, R.; Iliadis, A.; Ciccolini, J. Optimizing druggability through liposomal formulations: New approaches to an old concept. ISRN Pharm. 2012, 2012, 738432. [CrossRef]

90. Kshirsagar, N.A.; Pandya, S.K.; Kirodian, G.B.; Sanath, S. Liposomal drug delivery system from laboratory to clinic. J. Postgrad. Med. 2005, 51 (Suppl. S1), S5-S15.

91. Henry, B.D.; Neill, D.R.; Becker, K.A.; Gore, S.; Bricio-Moreno, L.; Ziobro, R.; Edwards, M.J.; Muhlemann, K.; Steinmann, J.; Kleuser, B.; et al. Engineered liposomes sequester bacterial exotoxins and protect from severe invasive infections in mice. Nat. Biotechnol. 2015, 33, 81-88. [CrossRef] [PubMed]

92. Yoo, J.W.; Chambers, E.; Mitragotri, S. Factors that control the circulation time of nanoparticles in blood: Challenges, solutions and future prospects. Curr. Pharm. Des. 2010, 16, 2298-2307. [CrossRef] [PubMed]

93. Alexis, F.; Pridgen, E.; Molnar, L.K.; Farokhzad, O.C. Factors affecting the clearance and biodistribution of polymeric nanoparticles. Mol. Pharm. 2008, 5, 505-515. [CrossRef] [PubMed]

94. Knop, K.; Hoogenboom, R.; Fischer, D.; Schubert, U.S. Poly(ethylene glycol) in drug delivery: Pros and cons as well as potential alternatives. Angew. Chem. Int. Ed. Engl. 2010, 49, 6288-6308. [CrossRef] [PubMed]

95. Hu, C.M.; Zhang, L.; Aryal, S.; Cheung, C.; Fang, R.H.; Zhang, L. Erythrocyte membrane-camouflaged polymeric nanoparticles as a biomimetic delivery platform. Proc. Natl. Acad. Sci. USA 2011, 108, 10980-10985. [CrossRef] [PubMed]

96. Hu, C.M.; Fang, R.H.; Copp, J.; Luk, B.T.; Zhang, L. A biomimetic nanosponge that absorbs pore-forming toxins. Nat. Nanotechnol. 2013, 8, 336-340. [CrossRef] [PubMed]

97. Escajadillo, T.; Olson, J.; Luk, B.T.; Zhang, L.; Nizet, V. A red blood cell membrane-camouflaged nanoparticle counteracts streptolysin O-mediated virulence phenotypes of invasive group A Streptococcus. Front. Pharmacol. 2017, 8, 477. [CrossRef]

98. Zhang, Y.; Gao, W.; Chen, Y.; Escajadillo, T.; Ungerleider, J.; Fang, R.H.; Christman, K.; Nizet, V.; Zhang, L. Self-assembled colloidal gel using cell membrane-coated nanosponges as building blocks. ACS Nano 2017, 11, 11923-11930. [CrossRef]

99. Chen, Y.; Chen, M.; Zhang, Y.; Lee, J.H.; Escajadillo, T.; Gong, H.; Fang, R.H.; Gao, W.; Nizet, V.; Zhang, L. Broad-spectrum neutralization of pore-forming toxins with human erythrocyte membrane-coated nanosponges. Adv. Healthc. Mater. 2018, 7, e1701366. [CrossRef] 
100. Wilke, G.A.; Bubeck Wardenburg, J. Role of a disintegrin and metalloprotease 10 in Staphylococcus aureus alpha-hemolysin-mediated cellular injury. Proc. Natl. Acad. Sci. USA 2010, 107, 13473-13478. [CrossRef]

101. Ludwig, A.; Hundhausen, C.; Lambert, M.H.; Broadway, N.; Andrews, R.C.; Bickett, D.M.; Leesnitzer, M.A.; Becherer, J.D. Metalloproteinase inhibitors for the disintegrin-like metalloproteinases ADAM10 and ADAM17 that differentially block constitutive and phorbol ester-inducible shedding of cell surface molecules. Comb. Chem. High Throughput Screen 2005, 8, 161-171. [CrossRef]

102. Inoshima, N.; Wang, Y.; Bubeck Wardenburg, J. Genetic requirement for ADAM10 in severe Staphylococcus aureus skin infection. J. Investig. Dermatol. 2012, 132, 1513-1516. [CrossRef]

103. Sampedro, G.R.; DeDent, A.C.; Becker, R.E.; Berube, B.J.; Gebhardt, M.J.; Cao, H.; Bubeck Wardenburg, J. Targeting Staphylococcus aureus alpha-toxin as a novel approach to reduce severity of recurrent skin and soft-tissue infections. J. Infect. Dis. 2014, 210, 1012-1018. [CrossRef] [PubMed]

104. Alonzo, F., 3rd; Kozhaya, L.; Rawlings, S.A.; Reyes-Robles, T.; DuMont, A.L.; Myszka, D.G.; Landau, N.R.; Unutmaz, D.; Torres, V.J. CCR5 is a receptor for Staphylococcus aureus leukotoxin ED. Nature 2013, 493, 51-55. [CrossRef]

105. Reyes-Robles, T.; Alonzo, F., 3rd; Kozhaya, L.; Lacy, D.B.; Unutmaz, D.; Torres, V.J. Staphylococcus aureus leukotoxin ED targets the chemokine receptors CXCR1 and CXCR2 to kill leukocytes and promote infection. Cell Host Microbe 2013, 14, 453-459. [CrossRef]

106. Dowd, K.J.; Farrand, A.J.; Tweten, R.K. The cholesterol-dependent cytolysin signature motif: A critical element in the allosteric pathway that couples membrane binding to pore assembly. PLoS Pathog. 2012, 8, e1002787. [CrossRef]

107. LaChapelle, S.; Tweten, R.K.; Hotze, E.M. Intermedilysin-receptor interactions during assembly of the pore complex: Assembly intermediates increase host cell susceptibility to complement-mediated lysis. J. Biol. Chem. 2009, 284, 12719-12726. [CrossRef]

108. Johnson, S.; Brooks, N.J.; Smith, R.A.; Lea, S.M.; Bubeck, D. Structural basis for recognition of the pore-forming toxin intermedilysin by human complement receptor CD59. Cell Rep. 2013, 3, 1369-1377. [CrossRef] [PubMed]

109. Cai, B.; Xie, S.; Liu, F.; Simone, L.C.; Caplan, S.; Qin, X.; Naslavsky, N. Rapid degradation of the complement regulator, CD59, by a novel inhibitor. J. Biol. Chem. 2014, 289, 12109-12125. [CrossRef]

110. Wu, Q.; Guo, Z. Glycosylphosphatidylinositols are potential targets for the development of novel inhibitors for aerolysin-type of pore-forming bacterial toxins. Med. Res. Rev. 2010, 30, 258-269. [CrossRef] [PubMed]

111. Ohno-Iwashita, Y.; Iwamoto, M.; Ando, S.; Iwashita, S. Effect of lipidic factors on membrane cholesterol topology-mode of binding of theta-toxin to cholesterol in liposomes. Biochim. Biophysica. Scta 1992, 1109, 81-90. [CrossRef]

112. Maron, D.J.; Fazio, S.; Linton, M.F. Current perspectives on statins. Circulation 2000, 101, 207-213. [CrossRef] [PubMed]

113. Rosch, J.W.; Boyd, A.R.; Hinojosa, E.; Pestina, T.; Hu, Y.; Persons, D.A.; Orihuela, C.J.; Tuomanen, E.I. Statins protect against fulminant pneumococcal infection and cytolysin toxicity in a mouse model of sickle cell disease. J. Clin. Investig. 2010, 120, 627-635. [CrossRef] [PubMed]

114. Statt, S.; Ruan, J.W.; Hung, L.Y.; Chang, C.Y.; Huang, C.T.; Lim, J.H.; Li, J.D.; Wu, R.; Kao, C.Y. Statin-conferred enhanced cellular resistance against bacterial pore-forming toxins in airway epithelial cells. Am. J. Resrir. Cell Mol. Biol. 2015, 53, 689-702. [CrossRef] [PubMed]

115. Henning-Knechtel, A.; Knechtel, J.; Magzoub, M. DNA-assisted oligomerization of pore-forming toxin monomers into precisely-controlled protein channels. Nuclear Acids Res. 2017, 45, 12057-12068. [CrossRef] [PubMed]

116. Alouf, J.E. Cholesterol-binding cytolytic protein toxins. Int. J. Med. Microbiol. 2000, 290, 351-356. [CrossRef]

117. Majd, S.; Yusko, E.C.; Billeh, Y.N.; Macrae, M.X.; Yang, J.; Mayer, M. Applications of biological pores in nanomedicine, sensing, and nanoelectronics. Curr. Opin. Biotechnol. 2010, 21, 439-476. [CrossRef]

118. Bischofberger, M.; Gonzalez, M.R.; van der Goot, F.G. Membrane injury by pore-forming proteins. Curr. Opin. Cell Biol. 2009, 21, 589-595. [CrossRef]

119. Bezrukov, S.M.; Nestorovich, E.M. Inhibiting bacterial toxins by channel blockage. Pathog. Dis. 2016, 74, ftv113. [CrossRef]

120. Nestorovich, E.M.; Bezrukov, S.M. Obstructing toxin pathways by targeted pore blockage. Chem. Rev. 2012, 112, 6388-6430. [CrossRef] 
121. Davis, M.E.; Brewster, M.E. Cyclodextrin-based pharmaceutics: Past, present and future. Nat. Rev. Drug Discov. 2004, 3, 1023-1035. [CrossRef] [PubMed]

122. Yannakopoulou, K.; Jicsinszky, L.; Aggelidou, C.; Mourtzis, N.; Robinson, T.M.; Yohannes, A.; Nestorovich, E.M.; Bezrukov, S.M.; Karginov, V.A. Symmetry requirements for effective blocking of pore-forming toxins: Comparative study with alpha-, beta-, and gamma-cyclodextrin derivatives. Antimicrob. Agents Chemother. 2011, 55, 3594-3597. [CrossRef]

123. Karginov, V.A.; Nestorovich, E.M.; Schmidtmann, F.; Robinson, T.M.; Yohannes, A.; Fahmi, N.E.; Bezrukov, S.M.; Hecht, S.M. Inhibition of S. aureus alpha-hemolysin and B. anthracis lethal toxin by beta-cyclodextrin derivatives. Bioorg. Med. Chem. 2007, 15, 5424-5431. [CrossRef] [PubMed]

124. Ragle, B.E.; Karginov, V.A.; Bubeck Wardenburg, J. Prevention and treatment of Staphylococcus aureus pneumonia with a beta-cyclodextrin derivative. Antimicrob. Agents Chemother. 2010, 54, 298-304. [CrossRef] [PubMed]

125. Melo, M.C.; Teixeira, L.R.; Pol-Fachin, L.; Rodrigues, C.G. Inhibition of the hemolytic activity caused by Staphylococcus aureus alpha-hemolysin through isatin-Schiff copper(II) complexes. FEMS Microbiol. Lett. 2016, 363, fnv207. [CrossRef] [PubMed]

126. Lewis, M.; Weaver, C.D.; McClain, M.S. Identification of small molecule inhibitors of Clostridium perfringens $\varepsilon$-Toxin cytotoxicity using a cell-based high-throughput screen. Toxins 2010, 2, 1825-1847. [CrossRef] [PubMed]

127. Cassidy, S.K.; O'Riordan, M.X. More than a pore: The cellular response to cholesterol-dependent cytolysins. Toxins 2013, 5, 618-636. [CrossRef]

128. Mesquita, F.S.; Brito, C.; Cabanes, D.; Sousa, S. Control of cytoskeletal dynamics during cellular responses to pore forming toxins. Commun. Integr. Biol. 2017, 10, e1349582. [CrossRef]

129. McNeil, P.L.; Kirchhausen, T. An emergency response team for membrane repair. Nat. Rev. Mol. Cell Biol. 2005, 6, 499-505. [CrossRef]

130. Romero, M.; Keyel, M.; Shi, G.; Bhattacharjee, P.; Roth, R.; Heuser, J.E.; Keyel, P.A. Intrinsic repair protects cells from pore-forming toxins by microvesicle shedding. Cell Death Differ. 2017, 24, 798-808. [CrossRef]

131. Keyel, P.A.; Loultcheva, L.; Roth, R.; Salter, R.D.; Watkins, S.C.; Yokoyama, W.M.; Heuser, J.E. Streptolysin O clearance through sequestration into blebs that bud passively from the plasma membrane. J. Cell Sci. 2011, 124, 2414-2423. [CrossRef] [PubMed]

132. Gurcel, L.; Abrami, L.; Girardin, S.; Tschopp, J.; van der Goot, F.G. Caspase-1 activation of lipid metabolic pathways in response to bacterial pore-forming toxins promotes cell survival. Cell 2006, 126, 1135-1145. [CrossRef] [PubMed]

133. Yarovinsky, T.O.; Monick, M.M.; Husmann, M.; Hunninghake, G.W. Interferons increase cell resistance to Staphylococcal alpha-toxin. Infect. Immun. 2008, 76, 571-577. [CrossRef] [PubMed]

134. Rayner, C.F.; Jackson, A.D.; Rutman, A.; Dewar, A.; Mitchell, T.J.; Andrew, P.W.; Cole, P.J.; Wilson, R. Interaction of pneumolysin-sufficient and -deficient isogenic variants of Streptococcus pneumoniae with human respiratory mucosa. Infect. Immun. 1995, 63, 442-447. [PubMed]

135. Lucas, R.; Czikora, I.; Sridhar, S.; Zemskov, E.; Gorshkov, B.; Siddaramappa, U.; Oseghale, A.; Lawson, J.; Verin, A.; Rick, F.G.; et al. Mini-review: Novel therapeutic strategies to blunt actions of pneumolysin in the lungs. Toxins 2013, 5, 1244-1260. [CrossRef]

136. Semenza, G.L. Oxygen homeostasis. Wiley Interdiscip. Rev. Syst. Biol. Med. 2010, 2, 336-361. [CrossRef]

137. Bellier, A.; Chen, C.S.; Kao, C.Y.; Cinar, H.N.; Aroian, R.V. Hypoxia and the hypoxic response pathway protect against pore-forming toxins in C. elegans. PLoS Pathog. 2009, 5, e1000689. [CrossRef]

138. Peyssonnaux, C.; Datta, V.; Cramer, T.; Doedens, A.; Theodorakis, E.A.; Gallo, R.L.; Hurtado-Ziola, N.; Nizet, V.; Johnson, R.S. HIF-1alpha expression regulates the bactericidal capacity of phagocytes. J. Clin. Investig. 2005, 115, 1806-1815. [CrossRef]

139. Bruick, R.K.; McKnight, S.L. A conserved family of prolyl-4-hydroxylases that modify HIF. Science 2001, 294, 1337-1340. [CrossRef]

140. Okumura, C.Y.; Hollands, A.; Tran, D.N.; Olson, J.; Dahesh, S.; von Kockritz-Blickwede, M.; Thienphrapa, W.; Corle, C.; Jeung, S.N.; Kotsakis, A.; et al. A new pharmacological agent (AKB-4924) stabilizes hypoxia inducible factor-1 (HIF-1) and increases skin innate defenses against bacterial infection. J. Mol. Med. 2012, 90, 1079-1089. [CrossRef] 
141. Banks, D.J.; Bradley, K.A. SILENCE: A new forward genetic technology. Nat. Method 2007, 4, 51-53. [CrossRef] [PubMed]

142. Carette, J.E.; Guimaraes, C.P.; Varadarajan, M.; Park, A.S.; Wuethrich, I.; Godarova, A.; Kotecki, M.; Cochran, B.H.; Spooner, E.; Ploegh, H.L.; et al. Haploid genetic screens in human cells identify host factors used by pathogens. Science 2009, 326, 1231-1235. [CrossRef] [PubMed]

143. Popov, L.M.; Marceau, C.D.; Starkl, P.M.; Lumb, J.H.; Shah, J.; Guerrera, D.; Cooper, R.L.; Merakou, C.; Bouley, D.M.; Meng, W.; et al. The adherens junctions control susceptibility to Staphylococcus aureus alpha-toxin. Proc. Natl. Acad. Sci. USA 2015, 112, 14337-14342. [CrossRef] [PubMed]

144. Ivie, S.E.; Fennessey, C.M.; Sheng, J.; Rubin, D.H.; McClain, M.S. Gene-trap mutagenesis identifies mammalian genes contributing to intoxication by Clostridium perfringens epsilon-toxin. PLoS ONE 2011, 6, e17787. [CrossRef] [PubMed]

145. Meijer, A.J.; Codogno, P. Autophagy: Regulation and role in disease. Crit. Rev. Clin. Lab. Sci. 2009, 46, 210-240. [CrossRef] [PubMed]

146. Levine, B.; Yuan, J. Autophagy in cell death: An innocent convict? J. Clin. Investig. 2005, 115, $2679-2688$. [CrossRef]

147. Mostowy, S. Autophagy and bacterial clearance: A not so clear picture. Cell Microbiol. 2013, 15, 395-402. [CrossRef]

148. Mathieu, J. Interactions between autophagy and bacterial toxins: Targets for therapy? Toxins 2015, 7, 2918-2958. [CrossRef]

149. Cockeran, R.; Anderson, R.; Feldman, C. Pneumolysin as a vaccine and drug target in the prevention and treatment of invasive pneumococcal disease. Arch. Immunol. Ther. Exp. 2005, 53, 189-198.

150. Grijalva, C.G.; Nuorti, J.P.; Arbogast, P.G.; Martin, S.W.; Edwards, K.M.; Griffin, M.R. Decline in pneumonia admissions after routine childhood immunisation with pneumococcal conjugate vaccine in the USA: A time-series analysis. Lancet 2007, 369, 1179-1186. [CrossRef]

151. Crisinel, P.A.; Chevalier, I.; Rallu, F.; Tapiero, B.; Lamarre, V.; Thibault, R.; Ovetchkine, P. Invasive pneumococcal disease after implementation of a reduced three-dose pneumococcal conjugate vaccine program: A pediatric tertiary care center experience. Eur. J. Pediatr. 2010, 169, 1311-1315. [CrossRef] [PubMed]

152. Leroux-Roels, G.; Maes, C.; De Boever, F.; Traskine, M.; Ruggeberg, J.U.; Borys, D. Safety, reactogenicity and immunogenicity of a novel pneumococcal protein-based vaccine in adults: A phase I/II randomized clinical study. Vaccine 2014, 32, 6838-6846. [CrossRef] [PubMed]

153. Alexander, J.E.; Lock, R.A.; Peeters, C.C.; Poolman, J.T.; Andrew, P.W.; Mitchell, T.J.; Hansman, D.; Paton, J.C. Immunization of mice with pneumolysin toxoid confers a significant degree of protection against at least nine serotypes of Streptococcus pneumoniae. Infect. Immun. 1994, 62, 5683-5688.

154. Ogunniyi, A.D.; Woodrow, M.C.; Poolman, J.T.; Paton, J.C. Protection against Streptococcus pneumoniae elicited by immunization with pneumolysin and CbpA. Infect. Immun. 2001, 69, 5997-6003. [CrossRef] [PubMed]

155. Denoel, P.; Philipp, M.T.; Doyle, L.; Martin, D.; Carletti, G.; Poolman, J.T. A protein-based pneumococcal vaccine protects rhesus macaques from pneumonia after experimental infection with Streptococcus pneumoniae. Vaccine 2011, 29, 5495-5501. [CrossRef] [PubMed]

156. Prymula, R.; Pazdiora, P.; Traskine, M.; Ruggeberg, J.U.; Borys, D. Safety and immunogenicity of an investigational vaccine containing two common pneumococcal proteins in toddlers: A phase II randomized clinical trial. Vaccine 2014, 32, 3025-3034. [CrossRef] [PubMed]

157. Kirkham, L.A.; Kerr, A.R.; Douce, G.R.; Paterson, G.K.; Dilts, D.A.; Liu, D.F.; Mitchell, T.J. Construction and immunological characterization of a novel nontoxic protective pneumolysin mutant for use in future pneumococcal vaccines. Infect. Immun. 2006, 74, 586-593. [CrossRef]

158. Cockeran, R.; Steel, H.C.; Theron, A.J.; Mitchell, T.J.; Feldman, C.; Anderson, R. Characterization of the interactions of the pneumolysoid, Delta6 PLY, with human neutrophils in vitro. Vaccine 2011, 29, 8780-8782. [CrossRef]

159. Farrand, A.J.; LaChapelle, S.; Hotze, E.M.; Johnson, A.E.; Tweten, R.K. Only two amino acids are essential for cytolytic toxin recognition of cholesterol at the membrane surface. Proc. Natl. Acad. Sci. USA 2010, 107, 4341-4346. [CrossRef] 
160. Mann, B.; Thornton, J.; Heath, R.; Wade, K.R.; Tweten, R.K.; Gao, G.; El Kasmi, K.; Jordan, J.B.; Mitrea, D.M.; Kriwacki, R.; et al. Broadly protective protein-based pneumococcal vaccine composed of pneumolysin toxoid-CbpA peptide recombinant fusion protein. J. Infect. Dis. 2014, 209, 1116-1125. [CrossRef]

161. Adhikari, R.P.; Karauzum, H.; Sarwar, J.; Abaandou, L.; Mahmoudieh, M.; Boroun, A.R.; Vu, H.; Nguyen, T.; Devi, V.S.; Shulenin, S.; et al. Novel structurally designed vaccine for S. aureus alpha-hemolysin: Protection against bacteremia and pneumonia. PLoS ONE 2012, 7, e38567. [CrossRef] [PubMed]

162. Adhikari, R.P.; Thompson, C.D.; Aman, M.J.; Lee, J.C. Protective efficacy of a novel alpha hemolysin subunit vaccine (AT62) against Staphylococcus aureus skin and soft tissue infections. Vaccine 2016, 34, 6402-6407. [CrossRef] [PubMed]

163. Zuo, Q.F.; Yang, L.Y.; Feng, Q.; Lu, D.S.; Dong, Y.D.; Cai, C.Z.; Wu, Y.; Guo, Y.; Gu, J.; Zeng, H.; et al. Evaluation of the protective immunity of a novel subunit fusion vaccine in a murine model of systemic MRSA infection. PLoS ONE 2013, 8, e81212. [CrossRef] [PubMed]

164. Hernandez-Flores, K.G.; Vivanco-Cid, H. Biological effects of listeriolysin O: Implications for vaccination. BioMed Res. Int. 2015, 2015, 360741. [CrossRef] [PubMed]

165. Carrero, J.A.; Vivanco-Cid, H.; Unanue, E.R. Listeriolysin o is strongly immunogenic independently of its cytotoxic activity. PLoS ONE 2012, 7, e32310. [CrossRef] [PubMed]

166. Michel, E.; Reich, K.A.; Favier, R.; Berche, P.; Cossart, P. Attenuated mutants of the intracellular bacterium Listeria monocytogenes obtained by single amino acid substitutions in listeriolysin O. Mol. Microbiol. 1990, 4, 2167-2178. [CrossRef] [PubMed]

167. Bahey-El-Din, M.; Casey, P.G.; Griffin, B.T.; Gahan, C.G. Expression of two Listeria monocytogenes antigens (P60 and LLO) in Lactococcus lactis and examination for use as live vaccine vectors. J. Med. Microbiol. 2010, 59, 904-912. [CrossRef] [PubMed]

168. Bokori-Brown, M.; Kokkinidou, M.C.; Savva, C.G.; Fernandes da Costa, S.; Naylor, C.E.; Cole, A.R.; Moss, D.S.; Basak, A.K.; Titball, R.W. Clostridium perfringens epsilon toxin H149A mutant as a platform for receptor binding studies. Protein Sci. 2013, 22, 650-659. [CrossRef]

169. Chiarot, E.; Faralla, C.; Chiappini, N.; Tuscano, G.; Falugi, F.; Gambellini, G.; Taddei, A.; Capo, S.; Cartocci, E.; Veggi, D.; et al. Targeted amino acid substitutions impair streptolysin O toxicity and group A Streptococcus virulence. mBio 2013, 4, e00387-12. [CrossRef]

170. Uchiyama, S.; Dohrmann, S.; Timmer, A.M.; Dixit, N.; Ghochani, M.; Bhandari, T.; Timmer, J.C.; Sprague, K.; Bubeck-Wardenburg, J.; Simon, S.I.; et al. Streptolysin O Rapidly Impairs Neutrophil Oxidative Burst and Antibacterial Responses to Group A Streptococcus. Front. Immunol. 2015, 6, 581. [CrossRef]

171. Hu, C.M.; Fang, R.H.; Luk, B.T.; Zhang, L. Nanoparticle-detained toxins for safe and effective vaccination. Nat. Nanotechnol. 2013, 8, 933-938. [CrossRef] [PubMed]

172. Hu, C.M.; Zhang, L. Nanotoxoid Vaccines. Nano Today 2014, 9, 401-404. [CrossRef] [PubMed] 